D. WEYER

\title{
LAMBELASMA NARVAENSE, A NEW RUGOSE CORAL FROM THE MIDDLE ORDOVICIAN OF ESTONIA
}

Rugosa of the family Lambelasmatidae dominate in Baltoscandian coral faunas of the Middle Ordovician and are widely distributed from Norway (Oslo district) and Sweden (Siljan district, Östergötland, Öland) to Estonia, Leningrad Region and Podolia; additionally they occur in Pleistocene erratic boulders throughout the northern German-Polish lowlands. Perforate laminar septa built of incompletely fused coarse long trabecular spines (monacanths) are the most important feature characterizing this ancient group (suborder Calostylina). Among Rugosan phylogeny, it represents one of the primary radiations, well flourishing and highly diversified already during Viruan times with the first coralla having invented axial bosses (Coelostylis), dissepiments (Neotryplasma), and everted calices (Calostylis). Lambelasmatidae continue into Harjuan times, but as a minor constituent of solitary Rugosa faunas, which then become predominated by Streptelasmatidae.

About 15 Ordovician species have been recorded from Baltoscandia. This number may be doubled from evidence of undescribed collections at the author's disposal. Most interesting are several new taxa of Lambelasma Weyer, 1973, a possible junior synonym of Lambeophyllum Okulitch, 1938; that genus offers good Caradocian index fossils (from Jōhvi to Nabala Stages). Lambelasma narvaense sp. n. to be proposed here was found both in Estonia (Rakvere Stage) and in the German Democratic Republic (Baltic Sea limestone of same age, Pleistocene drift).

The following list of Estonian Lambelasmatidae includes all previously erected species and some nomina nuda (descriptions in press). Two somewhat doubtful specimens are omitted: «Lambeophyllum (aff. Streptelasma compactum Hill, 1953)» (Кальо, 1956, p. 69) = «Lambeophyllum compactum (Hill, 1953)» (Ивановский, 1965, р. 10) from Idavere and Jõhvi Stages, «Primitophyllum primum Kaljo, 1956» (revised in Weyer, 1980, paratype No. Co1333 similar to Lambelasmatidae, not conspecific with holotype of unknown systematic position) from Jōhvi Stage. Morphological revisions of selected species have been published by D. Weyer $(1980,1982,1984)$. Remarkable gaps within the coral sequence during Keila, Nabala, and Pirgu Stages will be due to present imperfect knowledge. Unstudied faunas can be expected, especially those from Keila and Oandu Stages perhaps yielding Coelostylis Lindström, 1880 (Neuman, 1967), curiously missing up to now in Estonia. Existence of Lambelasmatids in strata corresponding to Nabala Stage is proved by German erratic Pleistocene drift materials (small collection from aphanitic limestone facies). 


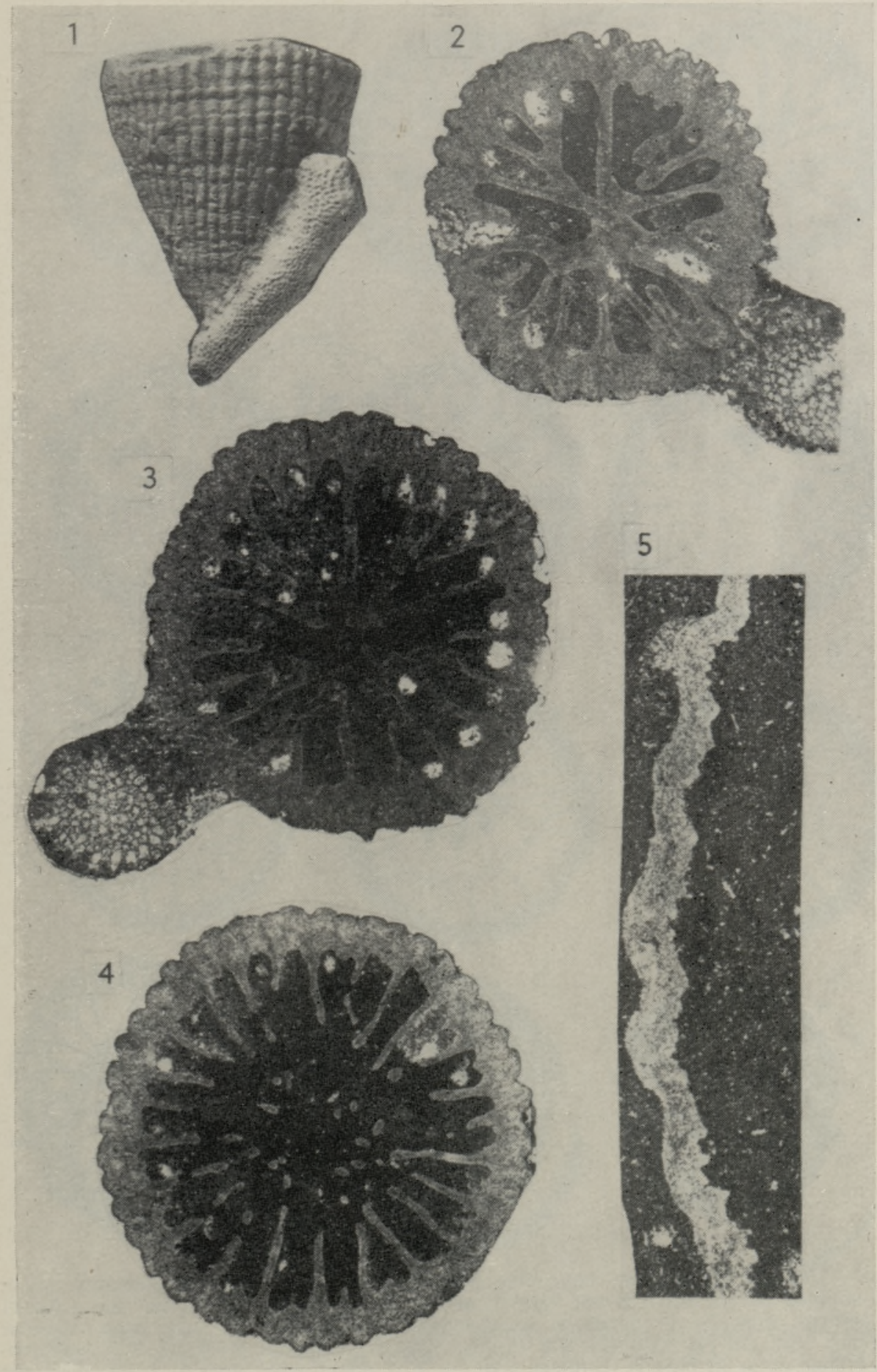

Plates I-III. Lambelasma narvaense sp. n., holotype No. Co1340 (Institute of Geology, Tallinn), Rakvere Stage, Skaryatina Gora near Narva River.

Fig. 1. Lateral view of corallum, $\times 2.5$. Figs $2-4$. Cross-sections of middle calicular regions, $\times 8(2-3)$ and $\times 7(4)$; drawings see PI. II, Fig. 12, and PI. III, Figs 2, 6 . Fig. 5. Multitrabecular septa of top calicular margin (detail from cross-section of PI. III, Fig. 12), $\times 20$. 
PLATE II

1
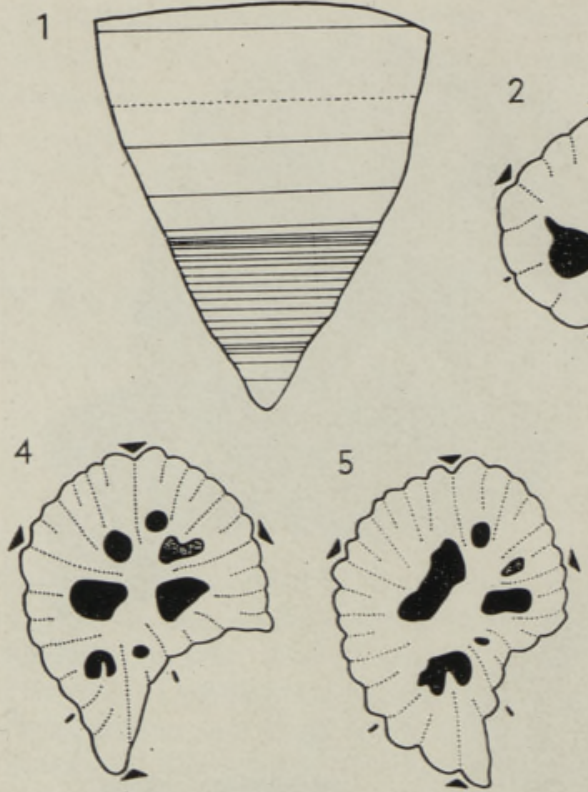

6
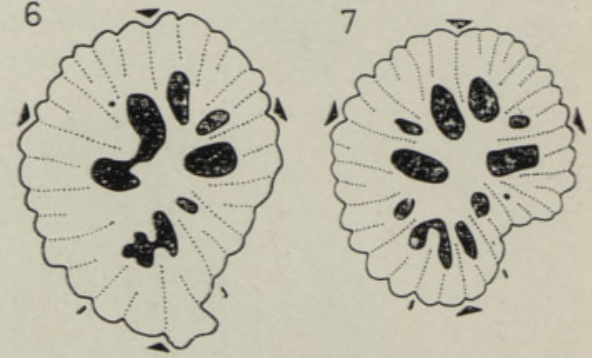

8
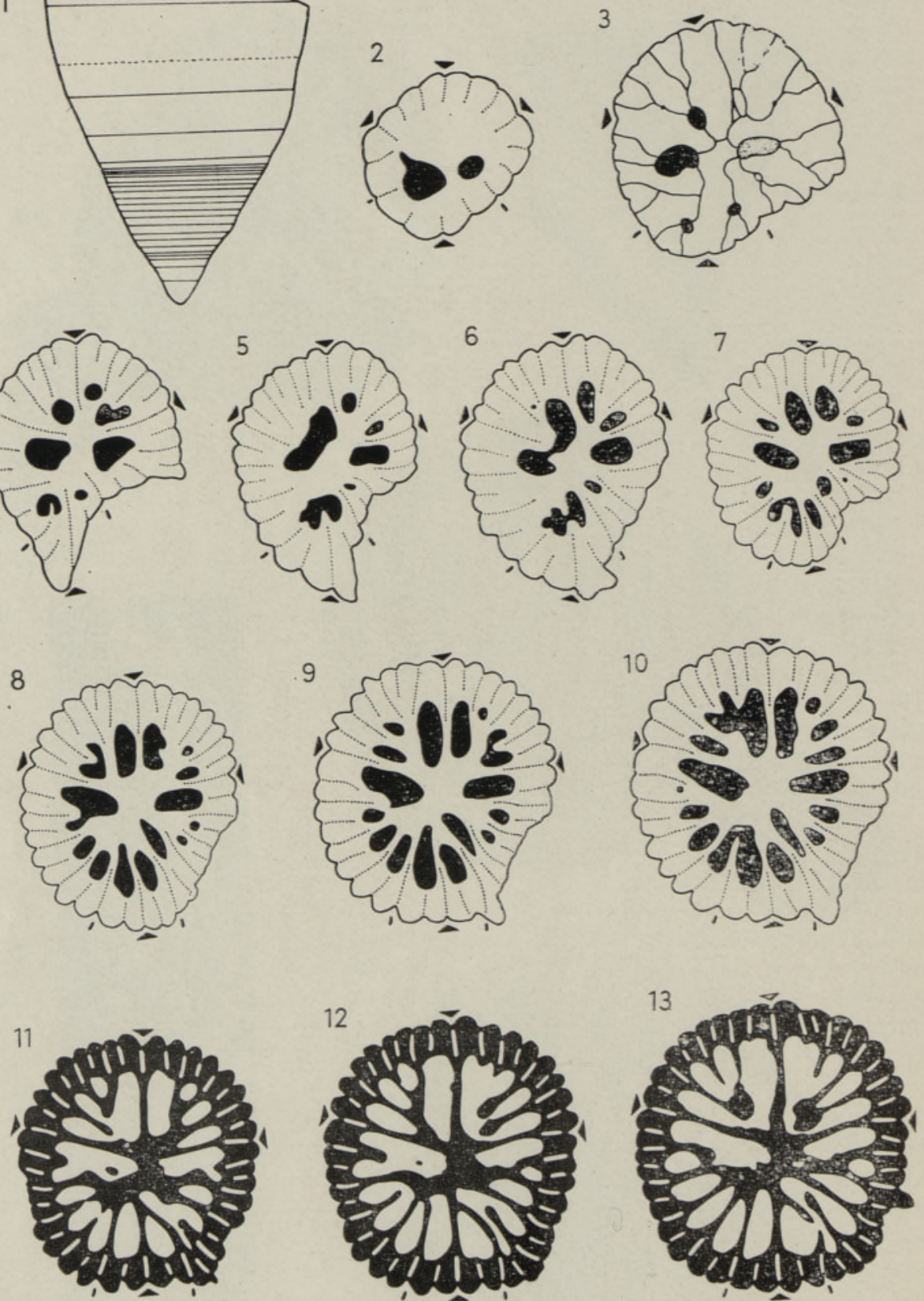

Fig. 1. Outline of corallum indicating positions of 25 prepared cross-sections, $\times 2.4$; the stippled section No. 2 is not figured; section No. 20 lying only $0.1 \mathrm{~mm}$ above No. 21 is omitted. Figs 2-13. Series of cross-sections from subtabular and lower calicular regions, $\times 12(2-3), \times 9.6(4), \times 8(5-6), \times 6.4 \quad(7-10)$, and $\times 5.6(11-13)$; subtabular lumina occur in Figs 2-7 (black areas of 2, 3, one stippled area of 4-7); distances from the basal section (2) count 0.9 (3), 1.3 (4), 1.5 (5), 1.7 (6), 2.0 (7), 2.4 (8), 2.7 (9), 3.1 (10), 3.5 (11), 3.8 (12), and $4.2 \mathrm{~mm}$ (13). 

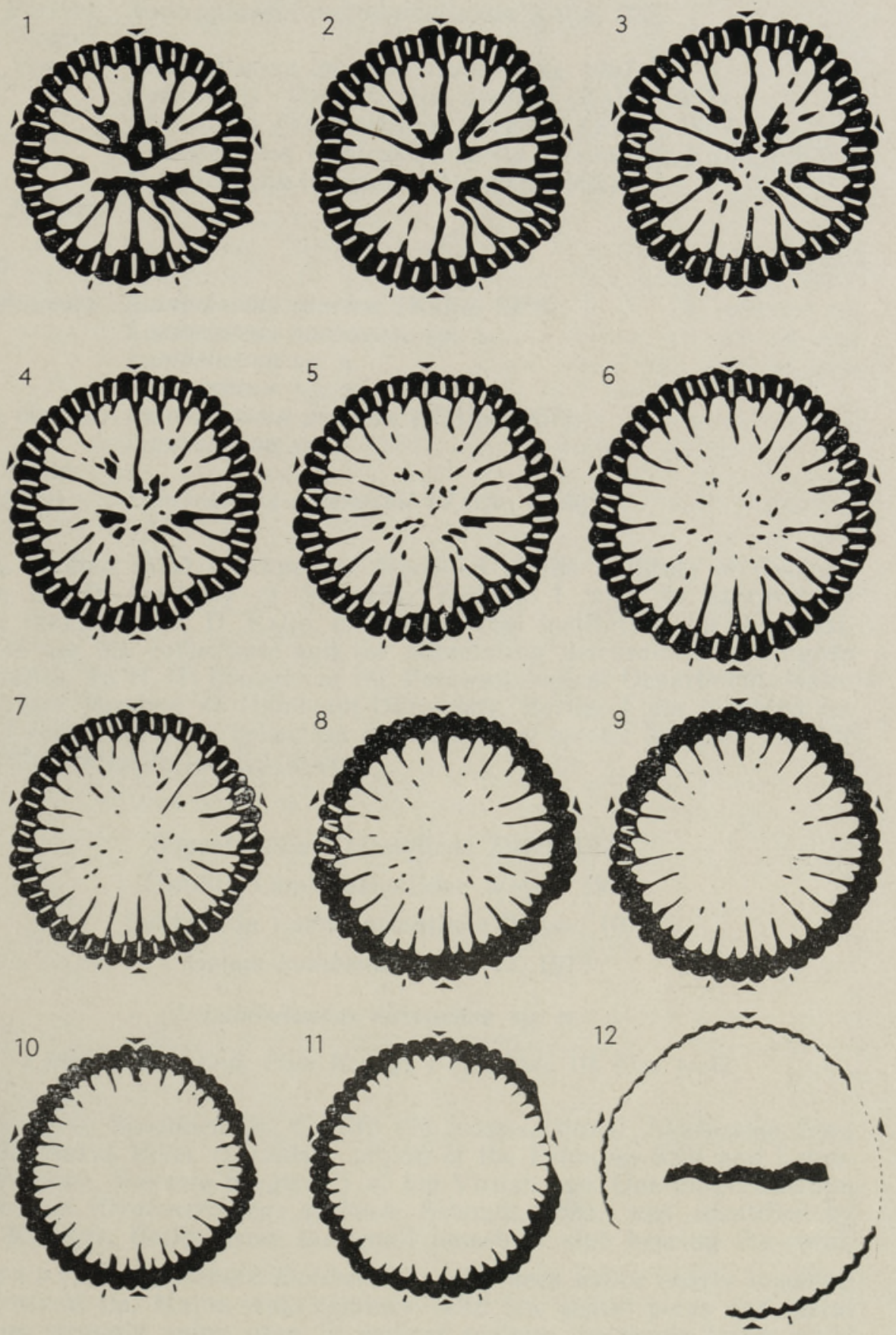

Figs 1-12. Series of cross-sections from middle and upper calicular regions (without subtabular areas), $\times 4.8(1-3), \times 4.4 \quad(4-6), \times 4 \quad(7-9), \times 3.2 \quad(10)$, and $\times 2.8$ $(11-12)$; distances from the basal cross-section of Pl. II, Fig. 2, count 4.5 (1), 4.9 (2), $5.2(3), 5.4(4), 5.7(5), 5.9(6), 6.0(7), 6.1(8), 6.5(9), 7.9(10), 10.0(11)$, and $14.7 \mathrm{~mm}(12)$; septal details within Fig. $12 \times 8$. 



\section{Harjuan}

$\mathrm{F}_{\mathrm{II}}$, Porkuni Neotryplasma codonophylloides Kaljo, 1957

$F_{\text {Ic }}$, Pirgu

?

$\mathrm{F}_{\mathrm{I}} \mathrm{b}$, Vormsi Neotryplasma longiseptatum Kaljo, 1957

Coelostylis (Vormsistylis) dentata (Kaljo, 1957)

Coelostylis (Vormsistylis)? bekkeri (Kaljo, 1957)

Estonielasma hemicymatelasma (Reiman in Kaljo, 1957)

$F_{I}$, Nabala

Estonielasma antiquum (Reiman, 1958)

\section{Viruan}

E, Rakvere Lambelasma atavum (Kaljo, 1958)

Lambelasma narvaense $\mathrm{sp} . \mathrm{n}$.

Lambelasma sp. $\mathrm{n}$.

Dybowskinia sp. $\mathrm{n}$.

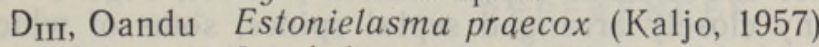

Lambelasma sp. $\mathrm{n}$.

$\mathrm{D}_{\text {II }}$, Keila

?

DI, Jõhvi Lambelasma dybowskii (Kaljo, 1956)

The studied coral specimen is deposited at the Institute of Geology of the ESSR Academy of Sciences, Tallinn. I wish to express my sincere thanks to Dr. D. Kaljo, director of that institution, for the possibility to see his collections and for stimulating discussions on Rugosa systematics. To H.-H. Krueger of the Palaeontological Department, Natural History Museum of Humboldt-University, Berlin, I am indebted for loan of corals from his collection of Pleistocene erratic boulders and for help with a trilobite identification.

Suprafamilia Calostylicae Zittel, 1879

Familia Lambelasmatidae Weyer, 1973

Subfamilia Lambelasmatinae Weyer, 1973

Genus Lambelasma Weyer, 1973

\section{Lambelasma narvaense sp. $\mathrm{n}$.}

Plate I, Figs 1-5; Plate II, Figs 1-13; Plate III, Figs 1-12

H o l o t y p e. Specimen No. Co1340 (26 cross-sections), Skaryatina Gora near the Narva River (boundary region of the Estonian SSR and Leningrad Region), Rakvere Stage (E) of top Viruan age. One mid-cranidium fragment of Erratencrinurus seebachi Schmidt, 1881, was identified by H.-H. Krueger, Berlin, from the small limestone slab bearing the coral.

D i a $\mathrm{g}$ os is. A trochoid Lambelasma with deep calice nearly reaching the proximal tip. Major septa laminar, with few septal pores and distal margins strongly spiny even in central regions. In levels below axial septal fusion, interseptal spaces are large in proportion to thin major septa.

Description. The excellently preserved monotype is a conical erect corallum of $17 \mathrm{~mm}$ in length, attached to a Bryozoan. Diameters of unbroken calicular margin and basal tip measure $14 \mathrm{~mm}$ and $0.5 \mathrm{~mm}$. External wall (archaeotheca) with fine growth rugae and coarse longitudinal sculpture. Broad interseptal ribs are flatly to well rounded; deep slender septal furrows show the pinnate arrangement according 
to the law of Kunth, with multiplication by splitting of old furrows connected with intercalation of new ribs. There are no additional «third order» furrows of hyposepta. Depth of calice amounts to $80 \%$ of corallum length.

The mature septal apparatus consists of 50 septa, 28 of which are major ones. Minor septa remain rather short and are active only in the upper calice; their generally biform reduction (incorporation into the wall) starts in middle calicular parts and is finished in the lower calice. Major septa reach the centre at about half the corallum height and fuse without forming an axial boss. Metasepta demonstrate a remarkable pinnate position in four quadrants. Cardinal septum of same length as other major septa, with an incipient very weak shortening in high calicular regions (PI. III, Figs 5-8, there surrounded in a somewhat fossulalike manner by neighbouring metasepta). Larger pseudofossulae occur near cardinal and lateral septa.

The central level just above axial septal fusion (Pl. III, Figs 5-6) is characterized by many closely arranged septal spines, some of which may be slightly thickened (rhopaloid) centripetally at their axial ends before fusing with next septa. Both axial stereozone and major septa (including their comparatively small massive areas of pinnately fused interior parts in four quadrants) of lower calice have little thickening by stereoplasm, thus leaving rather large interseptal lumina nearly to the calicular base.

The basal apparatus is weakly developed. There are some few convex and thick tabulae near the proximal tip, in addition to the predominating slight stereoplasmatic thickening of basal calicular skeletal elements.

Septal microstructure changes from a multitrabecular type of immediate calicular margin (Pl. III, Fig. 12) to thick and hyperlong monacanths. Fusion of single trabecular spines proceeds rather well, but with some remaining pores located in central as well as in peripheral septal parts, sometimes not closed even in the lowest calice (antiseptum of Figs $5-6$, Pl. II). The following formulae indicate septal ontogeny $(\mathrm{n}=$ number of major septa, $\mathrm{N}=$ number of all septa, $\mathrm{D}=$ diameter) :

$\frac{1}{2}\left|\frac{1}{2} \quad \frac{2}{3}\right| \frac{2}{3} \quad \frac{3}{4}\left|\frac{3}{4} \quad \frac{3}{5}\right| \frac{4}{5} \quad \frac{4}{5}\left|\frac{4}{5} \quad \frac{4}{6}\right| \frac{4}{6}$

$\begin{array}{lllllll}\mathrm{n} & 10 & 14 & 18 & 21 & 22 & 24 \\ \mathrm{~N} & 15 & 22 & 28 & 34-35 & 36-38 & 41 \\ \mathrm{D} \text { (mm) } & 1.9 & 2.5 & 2.6-3.4 & 3.8-4.9 & 5.2-5.9 & 6.4-6.8 \\ \text { pl./fig. } & \mathrm{II} / 2 & \mathrm{II} / 3 & \mathrm{II} / 4-6 & \mathrm{II} / 7-9 & \mathrm{II} / 10-12 & \mathrm{II} / 13, \mathrm{III} / 1\end{array}$

$\begin{array}{lllll} & \frac{4}{6} \mid \frac{5}{6} & \frac{5}{6} \mid \frac{5}{6} & \frac{5}{7} \mid \frac{5}{6} & \frac{5}{7} \mid \frac{5}{7} \\ \mathrm{n} & 25 & 26 & 27 & 28 \\ \mathrm{~N} & 43-44 & 46 & 47 & 48-50 \\ \mathrm{D}(\mathrm{mm}) & 7.1-8.1 & 8.5 & 8.9-9.0 & 10.2-13.6 \\ \text { pl./fig. } & \text { III } / 2-5 & \text { III/6-7 } & \text { III } / 8-9 & \text { III/10-12 }\end{array}$

\section{Discussion}

Lambelasma lambei Weyer, 1973 from the German Pleistocene drift Macrourus limestone (of Baltic Sea origin, stratigraphically corresponding to the Estonian Oandu Stage) is the closest of known species, with similar configuration of major septa (definite pinnate arrangement, well developed pseudofossula with slightly shortened cardinal septum), but differs in having much less spinous septal margins in central parts 
above axial fusion, and in building compact axial stereozone (at least two times wider) in lower calice, where interseptal chambers grow distinctly smaller due to stronger thickening of septa. Lambelasma dybowskii and Lambelasma atavum may be distinguished by their strongly porous, more spinous and less laminar septa, which are much thicker and bear coarser spines at distal margins (see Кальо, 1956, 1958). Additional separating features are hyposepta in Lambelasma dybowskii.

One specimen of Lambelasma narvaense has been collected from an aphanitic Baltic Sea (or «Wesenberg») limestone boulder in the Pleistocene drift of the German Democratic Republic (Weyer, 1984). Age determination based on accompanying fossils is either Rakvere or Nabala Stage.

\section{REFERENCES}

Neuman, B. The coral genus Coelostylis. - Geol. fören. i Stockholm förhandl., 1967, 88, 453-461.

Weyer, D. Ober den Ursprung der Calostylidae Zittel, 1879 (Anthozoa Rugosa, OrdovizSilur). - Freiberger Forschungshefte, 1973, C282, 33-87.

Weyer, D. Die älteste Rugose Koralle Europas (Primitophyllum Kaljo, 1956, Mittelordoviz). - Wissenschaftl. Beitr. Halle Univ., 1980, 30, 51-77.

Weyer, D. Das Rugosa-Genus Neotryplasma Kaljo, 1957 aus dem Ordoviz der europäischen UdSSR. - Freiberger Forschungshefte, 1982, C366, 89-95.

Weyer, D. Lambelasma-Arten (Anthozoa, Rugosa) aus dem baltoskandischen Mittelordoviz. - Freiberger Forschungshefte, 1984, C384, 7-19.

Нвановский $А$. Б. Стратиграфический и палеобиогеографический обзор ругоз ордовика и силура. М., 1965.

Кальо Д. Л. О стрептелазмидных ругозах прибалтийского ордовика. - Тр. Ин-та геол. АН ЭССР, 1956, I, 68-73.

Кальо Д. Л. Некоторые новые и малоизвестные ругозы Прибалтики. - Тр. Ин-та геол. АН ЭССР, 1958, III, 101-123.

DDR, Berlin

Received

Sept. 13, 1983

D. WEYER

\section{LAMBELASMA NARVAENSE, UUS RUGOOS EESTI KESKORDOVIITSIUMIST}

On kirjeldatud uut liiki perekonnast Lambelasma Weyer, 1973 (? võib-olla noorem sünonüüm perekonnale Lambeophyllum Okulitch, 1938). Materjal on leitud Rakvere lademest. kus domineerivad rugooside hulgas selle perekonna ja teised lambelasmatiidide esindajad.

\section{Д. ВЕНЕР}

\section{LAMBELASMA NARVAENSE, НОВЫИ ВиД РУГОЗ ИЗ СРЕДНЕГО ОРДОВИКА ЭСТОНИИ}

Описан вид из рода Lambelasma Wever, 1973 (? возможно, младший синоним родового названия Lambeophyllum Okulitch, 1938). Материал происходит из раквереского горизонта, в котором среди ругоз доминируют представители названного родз и другие ламбелазматиды. 